\title{
GAMBARAN KARAKTERISTIK IBU HAMIL YANG MENGALAMI KEKURANGAN ENERGI KRONIK DI PMB BIDAN IIS SUSILAWATI.,SST
}

\author{
Puzia Nurul Fadilah, Siti Fatimah \\ Universitas Galuh Ciamis \\ (puziapupu@gmail.com)
}

\begin{abstract}
ABSTRAK
Kekurangan Energi Kronik (KEK) adalah salah satu resiko kehamilan yang bisa menyebabkan timbulnya masalah pada kehamilan, persalinan dan masa nifas. Beberapa resiko yang paling banyak ditimbulkan dari permasalahan KEK yakni kejadian BBLR, persalinan prematur, dan anemia pada masa kehamilan. Tujuan dari penelitan ini adalah untuk mengetahui gambaran karakteristik ibu hamil yang mengalami Kekurangan Energi Kronik (KEK) di PMB Bidan Iis Susilawati., SST Tahun 2021. Jenis penelitian ini adalah penelitian kuantitatif dan menggunakan rancangan desain deskriptif. Populasi pada penelitian ini adalah ibu hamil dengan jumlah sampel 23 responden dengan metode total sampling. Instrumen yang digunakan adalah kuesioner dan lembar ceklis. Hasil penelitian yang dilakukan kepada 23 responden diantaranya: Hampir seluruh ibu memiliki usia tidak beresiko sebanyak 20 orang (87\%), sebagian besar ibu hamil berpendidikan menengah sebanyak 18 orang $(78,3 \%)$, sebagian besar ibu paritas nulipara sebanyak 14 orang $(60,9 \%)$, hampir seluruh ibu tidak bekerja sebanyak 20 orang $(87 \%)$, Sebagian kecil memiliki jarak kehamilan beresiko sebanyak 5 orang $(21,7 \%)$ dan sebagian besar ibu hamil berpengetahuan cukup sebanyak 12 orang $(52,5)$. Bagi tenaga Kesehatan khususnya bidan diharapkan lebih optimal dalam memberikan Pendidikan Kesehatan agar resiko kehamilan KEK ini tidak menyebabkan permasalahan yang berkelanjutan.
\end{abstract}

Kata Kunci : Kehamilan, KEK, Karakteristik

\section{ABSTRACT}

Chronic Deficiency Energy(CED) is one of the risks of pregnancy that can lead to problems with pregnancy, labor, and the postpartum period. Some of the most inconsiderable risks of CED problems are the incidence of BBLR, premature labor, and anemia during the pregnancy period. This research aims to know the characteristics of an expectant mother who is experiencing Chronic Deficiency Energy (CED) in PMB Midwife Iis Susilawati., SST 2021. This type of research is quantitative and uses descriptive design. The population in this research is the pregnant mother with the number of samples 23 respondents by the total method of sampling. The instruments used in this research are questionnaires and check pages. the result of this research on 23 of those respondents: nearly all mothers have an age of fewer than 20 people (87\%), a large percentage of middle-educated mothers as many as 18 (78.3\%), most mothers of nullipara as 14 (60.9\%), nearly all mothers do not work as much as 20 (87\%), a small percentage have as much risk gestation distance as 5 (21.7\%) and a large number of pregnant mothers have enough knowledge as many as 12 (52.5). For health workers in particular the midwife is expected to be more optimal in providing health education so that the risk of pregnancy at this point does not lead to the ongoing problem of pregnancy.

Keywords: pregnancy, characteristics, chronic energy deficienc 


\section{PENDAHULUAN}

Data yang di dapat dari Survei Penduduk Antar Sensus (SUPAS) pada tahun 2015 Angka Kematian Ibu (AKI) di Indonesia terdapat 305 kejadian per 100.000 kelahiran hidup. Dan masih dengan angka yang sama yakni 305 per 100.000 kelahiran hidup pada tahun 2019. Jika dibandingkan dengan data yang di dapat dari Survei Demografi dan Kesehatan Indonesia (SDKI) pada tahun 2012, AKI di Indonesia menurun dari angka 359 per 100.000 kelahiran hidup (Susiana Sali 2019). Penyebab kematian ibu dibagi menjadi penyebab langsung dan penyebab tidak langsung. Penyebab langsung yang menyebabkan terjadinya kematian pada ibu hamil adalah seperti adanya abortus, pendarahan antepartum, aborsi tidak aman (unsafe abortion), eklampsia, preeklampsia, dan infeksi. Adapun penyebab tidak langsung yang menjadi sebab kematian pada ibu hamil antara lain, faktor sosial budaya, status perempuan dalam keluarga, jumlah anak yang di miliki, keadaan ekonomi keluarga, dan geografi daerah. Salah satu faktor resiko yang menjadi penyebab tingginya AKI yang berpengaruh pada proses kehamilan dan persalinan adalah Kekurangan Energi Kronik (KEK).

KEK pada ibu hamil diakibatkan karena adanya defisiensi energi secara kronik. Pada ibu hamil, KEK bisa menyebabkan resiko pada kehamilan seperti anemia, abortus, kelahiran premature, intrauterine fetal deth (IUFD) intrauterine grow retradition (IUGR) dan juga penyebab tidak langsung kematian ibu. KEK juga bisa dipengaruhi oleh karakteristik seorang perempuan dimana penyerapan energi membutuhkan kondisi tubuh yang optimal sehingga penyerapannya baik.

Menurut Kemenkes RI pada tahun 2017 Jumlah kejadian KEK pada ibu hamil di Indonesia terdapat $16,2 \%$. Sedangkan itu, berdasarkan data yang didapatkan dari Riskesdas tahun 2018, prevlensi KEK pada ibu hamil di Indonesia sebesar 17,3\%. Di Jawa Barat prevalensi kejadian KEK pada ibu hamil terdapat 10,0\%(Dinas Kesehatan Provinsi Jawa Barat 2019). Di kabupaten Ciamis sendiri berdasarkan Dinas Kabupaten Ciamis angka kejadian KEK pada ibu hamil pada tahun 2020 mencapai angka 2055 (Pengantar 2013) PMB Bidan Iis merupakan salah satu PMB di Kecamatan Baregbeg Kabupaten Ciamis yang paling banyak melayani ibu hamil dengan resiko kehamilan KEK.

\section{METODE PENELITIAN}

Jenis penelitian yang digunakan adalah penelitian kuantitatif. Rancangan penelitian ini menggunakan metode deskriptif. Tujuan utama penelitian ini adalah untuk mengetahui gambaran karakteristik ibu hamil yang mengalami kekurangan energi kronik. Pengambilan 
sumber data menggunakan Teknik total sampling dengan jumlah responden 23 orang. Tempat dilakukan penelitian di PMB Bidan Iis Susilawati.,SST. Pengumpulan data dilakukan dengan cara memberikan kuesioner kepada responden. Pengolahan data menggunakan IBM SPSS (Statistical Package for Social Sciences) dan kemudian hasilnya dinarasikan untuk menjawab tujuan dari penelitian ini.

Penelitian ini didasarkan berdasarkan artikel yang didapat dari Google Scholar dengan jumlah 27 artikel nasional. Kata kunci dalam pencarian artikel adalah Kekurangan Energi Kronik pada ibu hamil. Salah satu penelitian yang serupa dengan penelitian ini adalah penelitian yang dilakukan oleh Anna Y.Pomalingo yang dilakukan di Kecamatan Tilango,Kabupaten Gorontalo dengan jenis penelitian yang digunakan adalah penelitian kuantitatif, rancangan penelitian yang digunakan adalah survey dengan pendekatan deskriptif. Populasi pada penelitian yakni sebanyak 18 orang dengan Teknik pengambilan sample menggunakan exhaustive sampling. Instrumen yang digunakan berupa kuesioner. Hasil Analisa yang didapat dari artikel Anna Y.Pomalingo pada tahun 2019 menyebutkan bahwa kekurangan Energi Kronik yang dialami oleh 18 orang ibu didapatkan 9 ibu hamil memiliki tingkat Pendidikan SD, 13 orang ibu hamil dengan paritas nullipara (belum pernah melahirkan), 11 orang ibu hamil yang berusia pada golongan usia tidak beresiko, 15 ibu hamil dengan kategori status bekerjaan Ibu Rumah Tangga (IRT), dan 13 orang ibu hamil dengan tingkat pengetahuan cukup.

\section{HASIL DAN PEMBAHASAN}

\section{Tabel.1 Distribusi Frekuensi Responden Berdasarkan Usia Ibu Hamil yang Mengalami KEK}

\begin{tabular}{cccc}
\hline No & Usia & Frekuensi & Persentase \\
\hline $\mathbf{1}$ & Beresiko & 20 & $87 \%$ \\
$\mathbf{2}$ & $\begin{array}{c}\text { Tidak } \\
\text { Beresiko }\end{array}$ & 3 & $13 \%$ \\
\hline Jumlah & & 23 & 100 \\
\hline
\end{tabular}

Sumber: Data Primer 2021

Berdasarkan Tabel.1 hasil penelitian yang dilakukan kepada 23 responden Ibu hamil yang mengalami KEK hampir seluruhnya memiliki usia yang tergolong pada usia beresiko yakni $<20$ tahun dan $>35$ tahun sebanyak 20 orang (87\%). Usia menjadi indikator yang penting pada status gizi manusia dikaitkan dengan proses kematangan organ-organ reproduksi manusia itu sendiri. Usia di golongkan menjadi dua yakni golongan beresiko $(<20$ tahun dan >35 tahun) dan usia yang tidak beresiko (20-35 Tahun). Ibu dengan usia yang terlalu muda ( $<20$ tahun) masih berada pada roses pertumbuhan sehingga asupan nutrisi yang ibu perlukan tidak cukup jika harus dibagi dengan janin yang dikandung. Maka, kehamilan pada usia yang terlalu muda akan menyebabkan adanya kompetisi dalam asupan nutrisi. 
Disisi lain ibu harus memenuhi kebutuhan nutrisinya sendiri, tapi disisi lain juga ibu harus memenuhi kebutuhan janin yang sedang ibu kandung. Selain itu juga ibu dengan usia <20 tahum belum memiliki kesempurnaan organ organ reproduksi sehingga memungkinkn terjadinya komplikasi pada saat kehamilan, persalinan, dan juga berpengaruh pada masa nifas dan output kehamilan itu sendiri. Adapun itu, ibu dengan usia >35 tahun juga menjadi kategori usia beresiko. Pada usia ini, organ ubuh ibu sudah mulai mengalami kemerosotan jaringan dan juga ibu mengalami peningkatan kebutuhan nutrisi.

\section{Tabel.2 Distribusi Frekuensi Responden Berdasarkan Pendidikan Ibu Hamil yang Mengalami Kekurangan Enrgi Kronik}

\begin{tabular}{cccc}
\hline NO & $\begin{array}{c}\text { Tingkat } \\
\text { Pendidikan }\end{array}$ & Frekuensi & Persentase \\
\hline $\mathbf{1}$ & Rendah & 4 & $17,4 \%$ \\
\hline $\mathbf{2}$ & Menengah & 18 & $78,3 \%$ \\
\hline $\mathbf{3}$ & Tinggi & 1 & $4,3 \%$ \\
\hline Jumlah & & 23 & 100 \\
\hline
\end{tabular}

Sumber: Data Primer 2021

Berdasarkan tabel.2 hasil penelitian yang dilakukan kepada 23 orang, sebagian besar responden yang mengalami kekurangan energi kronik pada masa kehamilan berada pada kategori pendidikan menengah sebanyak 18 orang $(78,3 \%)$. Pendidikan adalah akses untuk ibu mengetahui berbagai informasi. Semakin tinggi tingkat pendidikan ibu maka semakin besar akses untuk mengetahui berbagai hal termasuk mengenai kondisi kesehatannya.
Pada penelitian ini, ibu hamil yang mengalami KEK sebagian besar berada pada kategori Pendidikan menengah. Jika ditinjau secara teoritis, tingkat Pendidikan adalah salah satu faktor yang menunjang kualitas pengetahuan seseorang, sedangkan pengetahuan sendiri adalah faktor yang melatarbelakangi terbentuknya sikap dan perilaku seseorang (Notoatmoji 2012). Ibu dengan pendidikan menengah seharusnya sudah bisa bersikap terbuka dan memiliki pengetahuan yang tinggi atas resiko kehamilan yang ibu alami. Namun, pada kenyataannya ada juga ibu hamil dengan tingkat pendidikan menengah yang mengalami KEK pada masa kehamilan. Hal tersebut bisa disebabkan karena pendidikan ibu tidak berpengaruh pada pengetahuan ibu hamil. Dimana pengetahuan ibu bisa didapatkan karena akses dari berbagai media, penyuluhan, juga pengalaman ibu sendiri.

\section{Tabel.3 Distribusi Frekuensi}

Responden Berdasarkan Paritas Ibu Hamil yang Mengalami Kekurangan Enrgi Kronik

\begin{tabular}{cccc}
\hline No & Paritas & Frekuensi & Persentase \\
\hline $\mathbf{1}$ & Nulipara & 14 & $60,9 \%$ \\
\hline $\mathbf{2}$ & Primipara & 4 & $17,4 \%$ \\
\hline 3 & Multipara & 5 & $21,7 \%$ \\
\hline & Jumlah & 23 & $100 \%$ \\
\hline
\end{tabular}

\section{Sumber: Data Primer 2021}

Berdasarkan tabel.3 hasil penelitian yang dilakukan kepada 23 orang, sebagian besar responden yang mengalami kekurangan energi kronik pada masa kehamilan berada pada kategori paritas nulipara sebanyak 14 orang $(60,9 \%)$. 
Paritas adalah jumlah berapa kali ibu pernah melahirkan. Jumlah anak adalah salah satu faktor yang mempengaruhi keberhasilan proses konsepsi. Pada ibu hamil yang memiliki paritas tinggi permasalahan gizi bisa berdampak pada kondisi kesehatan ibu dan juga janin yang dikandung. Dalam hal ini angka paritas yang tinggi adalah jika ibu sudah lebih dari 3 kali melahirkan. Ibu yang sudah lebih 4 kali melahirkan beresiko megalami penurunan fungsi organ organ reroduksi sehingga asupan nutrisi ibu dikhususkan untuk memperbaiki kemerosotan tersebut. Perlu diperhatikan bahwa pada ibu yan sudah melahirkan anak lebih dari 3 kali atau lebih maka kemungkinan besar akan ditemui 2 permasalahan gizi yakni anemia dan kurang gizi serta kondisi dinding perut juga bagian rahim sudah mengalami kekendoran. Untuk mengetahui jumlah kelahiran ibu bisa dilakukan dengan cara anamnesa pada riwayat obstetrik pada saat dilakukan kunjungan antenatal care.

Meskipun demikian, pada penelitian ini kasus KEK banyak terjadi pada ibu hamil yang baru pertama kali hamil dan belum pernah mengalami proses persalinan. Hal tersebut bisa terjadi karena dipengaruhi oleh faktor psikologis dan kesiapan mental yang belum cukup sehingga ibu lebih mengabaikan dan cenderung tidak peduli terhadap asupan makanan yang seharusnya terpenuhi (Istiqomah, Qariati, and Dhewi 2020). Selain itu, pengetahuan dan pengalaman yang tidak cukup bisa mempengaruhi terjadinya KEK pada masa kehamilan

\section{Tabel.4 Distribusi Frekuensi \\ Responden Berdasarkan Status Pekerjaan Ibu Hamil yang Mengalami Kekurangan Energi Kronik}

\begin{tabular}{cccc}
\hline No & $\begin{array}{c}\text { Status } \\
\text { Pekerjaan }\end{array}$ & Frekuensi & Persentase \\
\hline $\mathbf{1}$ & Bekerja & 3 & $13 \%$ \\
\hline $\mathbf{2}$ & $\begin{array}{c}\text { Tidak } \\
\text { Bekerja }\end{array}$ & 20 & $87 \%$ \\
\hline & Jumlah & 23 & $100 \%$ \\
\hline
\end{tabular}

Sumber: Data Primer 2021

Berdasarkan tabel.4 hasil penelitian yang dilakukan kepada 23 orang, hamper seluruhnya responden yang mengalami kekurangan energi kronik pada masa kehamilan berada pada kategori status pekerjaan tidak bekerja sebanyak 20 orang (87\%). Status pekerjaan ibu hamil dikategorikan menjadi dua yakni ibu yang bekerja dan ibu yang tidak bekerja. Ibu dikatakan bekerja jika memiliki pekerjaan yang memungkinkan dirinya mendapatkan upah seperti pekerjaan sebagai pegawai negri, karyawan swasta, dan wiraswasta. Adapun ibu yang tidak bekerja adalah ibu yang menjadi ibu rumah tangga.

Pada kasus ini KEK banyak dialami oleh ibu hamil yang tidak bekerja atau sebagai ibu rumah tangga. Hal tersebut disebabkan karena ibu banyak mengeluarkan energi untuk mengurus keluarganya sehingga fokus ibu untuk memperhatikan kondisi kesehatan dan asupan makanannya berkurang. Selain itu, 
beraneka ragamnya pekerjaan rumah tangga yang ibu kerjakan sendiri menyebabkan ibu banyak bergerak. Dimana, semakin banyak aktifitas ibu maka semakin panyak pula energi yang dibutuhkan ibu. Status pekerjaan berkaitan dengan tingkat ekonomi seseorang. Ibu yang bekerja dan memiliki penghasilan sendiri memiliki kebebasan dan lebih leluasa untuk membeli dan mengosumsi makanan yang bernutrisi. Berbeda dengan ibu yang berstatus sebagai ibu rumah tangga yang hanya menggantungkan kebutuhanya kepada suami. Selain itu, status pekerjaan ibu pun bisa menunjang bagaimana ibu bersosialisasi. Yang dimana, ketika ibu terjun ke masyarakat dan bersosialisasi dengan orang banyak ibu akan lebih mudah dalam mendapatkan informasi tentang berbagai hal termasuk informasi mengenai kesehatannya.

5. Distribusi Frekuensi Responden Berdasarkan Jarak Kehamilan Ibu Hamil yang Mengalami Kekurangan Energi Kronik

\begin{tabular}{cccc}
\hline No & $\begin{array}{c}\text { Jarak } \\
\text { Kelahiran }\end{array}$ & Frekuensi & $\begin{array}{c}\text { Persenta } \\
\text { se }\end{array}$ \\
\hline $\mathbf{0}$ & $\begin{array}{c}\text { Belum } \\
\text { Pernah }\end{array}$ & 14 & $60,9 \%$ \\
\hline $\mathbf{1}$ & Beresiko & 5 & $21,7 \%$ \\
\hline $\mathbf{2}$ & $\begin{array}{c}\text { Tidak } \\
\text { Beresiko }\end{array}$ & 4 & $17,4 \%$ \\
\hline & Jumlah & 23 & $100 \%$
\end{tabular}

Sumber: Data Primer 2021

Berdasarkan tabel 5 hasil yang didapatkan dari 23 responden dengan mengesampingkan ibu yang memiliki paritas nulipara hampir seluruh responden memiliki jarak kelahiran pada kategori beresiko ( $<2$ tahun dan $>5$ tahun) sebanyak 5 responden (21,7\%). Jarak Jarak kehamilan digolongkan menjadi dua yakni jarak kehamilan yang beresiko (Jika jarak dari kehamilan pertama dengan kehamilan terakhir ibu $<2$ tahun dan $>5$ tahun) dan jarak kehamilan yang tidak beresiko (jika jarak kehamilan ibu yang pertama dengan kehamilan yang terakhir $>2$ dan tahun dan $<5$ tahun ). Jarak kehamilan menjadi salah satu indikator yang bisa menyebabkan terjadinya KEK pada ibu hamil. Hal ini dikaitkan dengan ketidaksiapan organorgan tubuh ibu mengalami kehamilan sebelum proses penyembuhan dan pengoptimalan organ-organ tubuh ibu setelah kelahiran yang sebelumnya. Selain itu, kondisi ibu yang masih menyusui memerlukan asupan gizi yang cukup untuk memperlancar proses menyusui. Kondisi ibu yang masih menyusui membutuhkan asupan kalori yang lebih banyak dengan tujuan untuk memperoleh ASI yang lebih baik. Jika pada kondisi ini ibu hamil lagi, maka besar kemungkinan akan timbul masalah yang bersangkutan dengan status gizi ibu dan janin yang dikandung. Kehamilan yang terlalu sering terjadi dengan rentang waktu yang terlalu akan menguras banyak zat nutrisi tubuh sehingga adanya gangguan pada metabolisme. Bersamaan dengan hal itu, tubuh akan tetap bermetabolisme sehingga cadangan gizi pada tubuh ibu digunakan dan 
menyebabkan tubuh kekurangan energi. Hal tersebut menyebabkan ibu mengalami KEK pada masa kehamilan. Jarak kehamilan $>5$ tahun pun menjadi kategori jarak kehamilan yang beresiko. WHO menyebutkan bahwa kemungkinan kelahiran prematur lebih meningkat jika ibu merencanakan kehamilan 5 tahun kemudian. Jarak kehamilan >5 tahun dapat memicu terjadinya berbagai komplikasi terlebih jika usia ibu sudah berada di kategori usia beresiko (>35 tahun). Dimana kehamilan yang terjadi pada usia >35 tahun bisa memicu banyak komplikasi kehamilan diantaranya adalah kekurangan Energi Kronik.

\section{Distribusi Frekuensi Responden Berdasarkan Pengetahuan Ibu Hamil yang Mengalami Kekurangan Energi Kronik}

\begin{tabular}{cccc}
\hline No & Pengetahuan & Frekuensi & Persentase \\
\hline $\mathbf{1}$ & Baik & 4 & $17,4 \%$ \\
\hline $\mathbf{2}$ & Cukup & 12 & $52,2 \%$ \\
\hline $\mathbf{3}$ & Kurang & 7 & $30,4 \%$ \\
\hline Jumlah & 23 & $100 \%$ \\
\hline
\end{tabular}

Berdasarkan tabel.6 hasil penelitian yang dilakukan kepada 23 orang, sebagian besar responden yang mengalami kekurangan energi kronik pada masa kehamilan memiliki tingkat pengetahuan cukup sebanyak 12 orang (52,2\%). Pengetahuan adalah segala sesuatu yang ibu ketahui mengenai Kekurangan Energi Kronik pada masa kehamilan. Pada penelitian ini pengetahuan ibu dikategorikan menjadi 3 yakni ibu yang memiliki pengetahuan baik (76-100\%), ibu yang memiliki pengetahuan cukup (56$76 \%$ ), dan ibu dengan pengetahuan yang kurang $(<56 \%)$.

Pengetahuan ibu menjadi salah satu in ikator yang dominan terhadap sikap ibu sendiri pada saat dihadapkan dengan permasalahan selama masa kehamilan. Ibu yang tahu dengan segala sesuatu yng berhubungan dengan permasalahan kehamilan cenderung bisa menentukan sikap yang harus di pertahankan dan diubah. Pengetahuan tentang zat gizi yang dibutuhkan selama masa kehamilan memotivasi ibu untuk selalu mengonsumsi makanan dengan nutrisi yang baik dan berusaha untuk menghindari KEK pada masa kehamilan.

Pada penelitian ini, Sebagian responden yang mengalami kekurangan energi kronik pada masa kehamilan memiliki pengetahuan yang cukup sebanyak 12 orang $(52,2 \%)$. Seharusnya, dengan pengetahuan yang tergolong cukup, kejadian KEK tidak dialami oleh ibu hamil. Akan tetapi, Jika didasarkan pada teori, seseorang bisa dikatakan tahu mengenai suatu hal jika sudah mencapai domain kognitif yang terdiri dari 6 tingkatan. 6 Tingkatan tersebut adalah tahu diartikan mampu mengingat suatu hal yang sebelumnya sudah dipelajari, memahami diartikan dengan kemampuan dalam menjelaskan secara berkesinambungan objek yang diketahui dan dapat 
menginterpetasikan materi yang diketahui tersebut secara benar. Adapun tingkatan pada seseorang yang dikatakan sudah berpengetahuan baik jika orang tersebut sudah bisa mengetahui, memahami keseluruhan objek, mengaplikasikan, menganalisis, sintesis dan mengevaluasi. Jadi, meskipun ibu memiliki pengetahuan yang cukup, itu bukan suatu hal yang bisa dijadikan patokan untuk ibu tidak mengalami KEK pada masa kehamilan. Karena ibu bisa saja hanya sekedar tahu dan belum seluruhnya memahami sehingga tidak ada proses mengaktualisasikan pengetahuan yang ibu miliki. Pengetahuan ibu ini bisa dipengaruhi oleh beberapa faktor, bisa karena status pendidikan, pengalaman ibu yang sudah mengalami dampak buruk dari KEK, dan juga peran petugas kesehatan dalam pemberian informasi ibu mengenai KEK itu sendiri.

\section{KESIMPULAN}

1. Hampir seluruh ibu hamil yang mengalami KEK berada pada kategori usia beresiko sebanyak 20 orang ( $87 \%$ )

2. Sebagian besar ibu hamil yang mengalami KEK berada pada kategori tingkat Pendidikan menengah sebanyak 18 orang $(78,3 \%)$

3. Sebagian besar ibu hamil yang mengalami KEK berada pada kategori paritas nulipara sebanyak 14 orang $(60,9 \%)$

4. Hampir seluruh bu hamil yang mengalami KEK memiliki status pekerjaan tidak bekerja sebanyak 20 orang $(87 \%)$.

5. Sebagian kecil ibu hamil yang mengalami KEK berada pada kategori jarak kehamilan beresiko sebanyak 5 orang $(21,7 \%)$

6. Sebagian besar ibu hamil yang mengalami KEK memiliki pengetahun yang cukup sebanyak 12 orang $(52,5 \%)$

\section{DAFTAR PUSTAKA}

Aryani P dkk, (2019) Faktor-faktor yang mempengaruhi kejadian kurang energi kronis (kek) pada ibu hamil di wilayah kerja upt Puskesmas I Pekutatan, Jembrana, Bali. Intisari Sains Medis.

Susiana Sali, (2019) Angka Kematian Ibu, Faktor Penyebab dan Upaya Penanganannya. Pus Penelit Badan Keahlian DPR RI.

Dinas Kesehatan Provinsi Jawa Barat, (2019) Profil Kesehatan Jawa Barat Chem Inf Model.

Stallaza Desta A, (2020) Hubungan Pantangan Makanan Terhadap Resiko Kekurangan Energi Kronik Pada Ibu Hamil. J Med Hutama.

Hikmah H dkk, (2020)Faktor Maternal dan Pola Makan Dengan Kejadian Kekurangan Energi Kronik Di Wilayah Kerja UPTD Puskesmas Kangkung. Jurnal Ilmu Kebidanan Malakbi

Pengantar K. Kabupaten Ciamis Tahun 2013. Ciamis

Indonesia KP dan KR, editor(2016) Kementerian Pendidikan dan Kebudayaan Republik Indonesia; 2016. Available from: https://www.kbbi.web.id/karakterist ik

Pomalingo AY, Misnati, Setiawan DI, (2019) Karakteristik Ibu Hamil Kurang Energi Kronis (KEK) di 
Kecamatan Tilango Kabupaten Gorontalo. Heal Nutr.

Baktiyani SCW, ;Meirani R, Khasanah U.(2012) Hubungan Atara Partus Lama Dengan Kejadian Perdarahan Pospartum Dini Di Kamar Bersalin Rumah Sakit Umum Dr. Saiful Anwar Malang. Maj Kesehat FKUB

Maritalia, (2017) Pengertian Kehamilan. Arch Community Heal

Walyani, (2015) Perawatan Kehamilan dan Menyusui Anak Pertama Agar Bayi Lahir dan Tumbuh Sehat. Jakarta

Hanim B, (2019) Analisis Penyebab Konstipasi Pada Ibu Hamil Di Wilayah Kerja Puskesmas Payung Sekaki Pekanbaru. J Ilm Kebidanan.

Dosen BI. Kebidanan Teori dan Asuhan Volume 1. 2018. Jakarta

Kebidanan DI V, Ngudi S, Ungaran W. Asuhan Kebidanan Ibu I. 2013; Available from https://docs.google.com/file/d/0Bw V6DNM2G4LtWVVhUk9oX3liW nM/edit

Rustikayanti, R.N. Rustikayanti, R. N., Kartika, I., \& Herawati Y. Perubahan Psikologi Ibu Hamil Trimester III. Southeast Asia J Midwifery. 2016;2.

Putri, Mutiara I, Ismiyatun N, (2020) Deteksi Dini Kehamilan Beresiko. J Kesehat Masyarakat

Didit. D, Pritasari, Nugraheni TL. Gizi Dalam Daur Kehidupan . 2017th ed. Jakarta: Kementrian Kesehatan R.I; 2017. Available from: http://bppsdmk.kemkes.go.id/pusdi ksdmk/wpcontent/uploads/2017/11/GIZIDALAM-DAUR-KEHIDUPANFINAL-SC.pdf

Andriani Z. (2015) Gambaran Status Gizi Ibu Hamil Berdasarkan Ukuran Lingkar Lengan Atas (LILA) di
Kelurahan Sukamaju Kota Depok. Fak Kedokt dan Ilmu Kesehat UIN Syarif Hidayatullah Jakarta.

Anggoro S, (2020) Studi Kesehatan Masyarakata P, Surya Global.S Hubungan Pola Makan (Karbohidrat dan Protein) Dengan Kejadian Kekurangan Energi Kronik pada Ibu Hamil di Puskesmas Pajangan Bantul Yogyakarta Relationship between Eating Patterns. https://journal.universitasbumigora. ac.id/index.php/nutroilogy/article/v iew/840

Adriani BA, (2019) Faktor yang berhubungan dengan kejadian kekurangan energi kronik (kek) pada ibu hamil.

Nugraha RN, Lalandos JL, Nurina RL, (2018) Hubungan Jarak Kehamilan dan Jumlah Paritas dengan Kejadian Kurang Energi Kronik pada Ibu Hamil di Kota Kupang. Cendana Med J.

Kesehatan K, (2016) Metodologi Penelitian. Jakarta: Kementrian Kesehatan R.I;

Kesehatan K, (2018) Metodologi Penelitian Kesehatan. 2018th ed. Masturoh I, Anggita N, editors. Jakarta: Kementrian Kesehatan R.I;

Istiqomah N, Qariati NI, Dhewi S, (2020) Hubungan Paritas, Status Pekerjaan, dan Riwayat Anemia Dengan Kejadian Kekurangan Energi Kronik (KEK) Pada Ibu Hamil Di Puskesmas Karang Intan 2 Kabupaten Banjar.

Ernawati A, (2018) Hubungan Usia Dan Status Pekerjaan Ibu Dengan Kejadian Kurang Energi Kronis Pada Ibu Hamil. J Litbang Media Inf Penelitian, Pengemb dan IPTEK. 